\title{
Analisis Proses Pemecahan Masalah Geometri Berdasarkan Teori Van Hiele di Sekolah Menengah Atas
}

\author{
M EB Indah \\ Universitas Muhammadiyah Sorong
}

Diterima: 2 Oktober 2016, Disetujui: 28 November 2016, Dipublikasikan:1 Desember 2016

\begin{abstract}
This study aims to explore and describe the process of problem solving geometry reach the level of visualization, analysis and informal deduction based on the Van Hiele theory. This type of research is descriptive explorative and qualitative approach. Subject of the study was obtained from the high school students who were tested on the level of Van Hiele geometry. Each level of visualization, analysis and informal deduction taken two learners who can communicate well. The results of this study indicate that solving problems in geometry learners who attained think visualization is to identify problems and set goals using the language question. Troubleshooting on the geometry of learners who attained think the analysis is through fifth troubleshooting step IDEAL using their own language, but less systematic. Troubleshooting on the geometry of students who reach a level of thinking is through the informal deduction fifth troubleshooting step IDEAL by systematically using their own language.
\end{abstract}

Keywords: problem-solving process, geometry, Van Hiele levels of thinking

\section{A. Pendahuluan}

Latar belakang

Pemecahan masalah merupakan pilar penting dalam mempelajari matematika (AlMigdady, 2014; Aydoğdu \& Keşan, 2014; NCTM, 2010). Mempelajari matematika diharuskan untuk berpikir agar mampu memahami konsep-konsep matematika yang dipelajari serta mampu menggunakan konsepkonsep tersebut secara tepat ketika menyelesaikan masalah (Saragih \& Habeahah, 2014; Muhassanah, 2014). Sesuai dengan tujuan pembelajaran geometri, maka peserta didik seharusnya menjadi pemecah masalah geometri yang baik. Tetapi dalam kenyataannya banyak peserta didik yang memiliki kesulitan dalam memecahkan masalah geometri (Abu \& Abidin, 2013; Muhassanah, 2014; Özerem, 2013).

Selain itu, data dari Balitbang (2012) menunjukkan bahwa daya serap ujian nasional tahun 2012 peserta didik SMP dan SMA di Jawa Timur maupun nasional untuk kompetensi geometri berada pada tingkat terendah dibandingkan kompetensi lainnya. Daya serap geometri pada ujian nasional SMP di Jawa Timur sebesar 75,95 sedangkan tingkat nasional sebesar 69,39. Daya serap geometri pada ujian nasional SMA di Jawa Timur sebesar 57,12 sedangkan tingkat nasional sebesar 63,77. Peserta didik lebih menganggap geometri lebih sulit dari pada kompetensi dalam matematika lainnya.

Sehubungan dengan kesulitan dalam belajar geometri maka guru sangat berperan penting dan aktif untuk menciptakan peserta didik yang memiliki kemampuan pemecahan masalah yang baik. Guru juga harus menguji tingkat berpikir geometri peserta didik berdasarkan teori Van Hiele untuk mengetahui sejauh mana peserta didik memahami materi geometri sehingga guru dapat mengatasi kesulitan peserta didik dalam belajar geometri.

Beberapa hasil penelitian tentang teori Van Hiele yang dilakukan sebelumnya menunjukkan kurangnya hasil belajar tentang geometri. Alex \& Mammen (2014) menyatakan bahwa mayoritas peserta didik kelas X SMA berada pada tingkat visualisasi. Khoiriyah, dkk (2014) menyatakan bahwa tingkat berpikir geometri peserta didik SMA berada pada tingkat analisis. Pinar (2014) menyatakan bahwa tingkat berpikir geometri peserta didik kelas IV, V, VI, dan VII berdasarkan teori Van Hiele masih rendah. 


\section{Jurnal Noken 2(1) 28-39 2016}

Berdasarkan latar belakang tersebut untuk meningkatkan kemampuan pemecahan masalah geometri maka guru perlu menganalisis proses pemecahan masalah geometri untuk mengetahui sejauh mana peserta didik memahami materi geometri. Sehingga penulis tertarik untuk menganalisis proses pemecahan masalah geometri berdasarkan teori Van Hiele karena penelitian sebelumnya hanya untuk mengetahui tingkat berpikir geometri berdasarkan teori Van Hiele belum sampai menganalisis proses pemecahan masalahnya.

Rumusan masalah

1. Bagaimana proses pemecahan masalah geometri peserta didik yang mencapai tingkat analisis berdasarkan teori Van Hiele?

Tujuan Penelitian

2. Untuk mengeksplorasi dan mendeskripsikan proses pemecahan masalah geometri peserta didik yang mencapai tingkat analisis berdasarkan teori Van Hiele.

\section{KAJIAN LITERATUR}

\subsection{Proses Pemecahan Masalah}

Suatu pertanyaan atau soal dalam pembelajaran matematika dikatakan suatu masalah jika dalam pertanyaan tersebut memuat tantangan tetapi belum diketahui prosedur rutin untuk menyelesaikannya (Kartono, 2013). Pemecahan masalah adalah proses menerapkan pengetahuan yang telah diperoleh sebelumnya ke dalam situasi baru yang belum dikenal. Sehingga suatu masalah bagi seseorang belum tentu merupakan masalah bagi orang lain karena setiap peserta didik mengetahui prosedur untuk menyelesaikannya.

Salah satu model pemecahan masalah yaitu IDEAL. Model ini dikenalkan oleh Bransford dan Stein sebagai model pemecahan masalah yang mampu meningkatkan kemampuan berpikir dan meningkatkan keterampilan proses pemecahan masalah (Susiana, 2010). IDEAL adalah singkatan dari $I$ Identify problem, D-Define goal, E-Explore possible strategies, A-anticipate outcomes and act, L-Look back dan learn (Prasetya, dkk, 2012; Kartono, 2013).
Pemecahan masalah IDEAL terdiri dari lima tahap (Purnomo \& Mawarsari, 2014; Sugiyanto \& Priyono, 2013; Prasetya, at el, 2012) di antaranya yaitu.

1. Mengidentifikasi masalah

Langkah pertama yaitu mengidentifikasi masalah dan menjadikannya sebagai suatu kesempatan untuk melakukan sesuatu yang kreatif. Jika suatu masalah tidak diidentifikasi maka strategi yang mungkin digunakan tidak akan dapat ditentukan

2. Menentukan tujuan

Sebuah masalah yang ada tergantung pada bagaimana mereka menentukan tujuan dan hal ini mempunyai efek yang penting terhadap tipe jawaban yang akan dicoba. Perbedaan dalam penentuan tujuan dapat menjadi penyebab yang sangat kuat terhadap kemampuan seseorang memahami masalah, berpikir dan menyelesaikan masalah.

3. Mencari strategi yang mungkin

Langkah ketiga yaitu mengeksplorasi strategi yang mungkin dan mengevaluasi kemungkinan strategi tersebut sesuai dengan tujuan yang telah ditetapkan.

4. Melaksanakan strategi

Melakukan langkah-langkah pemecahan masalah sesuai dengan strategi yang telah dipilih.

5. Mengkaji kembali dan mengevalusi pengaruhnya

Langkah terakhir yaitu mengkaji kembali akibat yang nyata dari strategi yang digunakan serta mengevalusi atau belajar dari pengalaman yang didapat. Melihat dan mengevaluasi perlu dilakukan karena setelah mendapatkan hasil, peserta didik banyak yang lupa untuk mengecek kembali dan belajar dari penyelesaian masalah yang telah dilakukan.

Tidak semua permasalahan dapat diselesaikan dalam satu kali langkah pengerjaan. Adakalanya jawaban yang didapat tidak sesuai dengan tujuan yang ditetapkan. Dalam penyelesaian masalah model IDEAL jika langkah kelima yaitu melihat kembali jawaban yang ada ternyata tidak sesuai dengan tujuan yang diinginkan belum tercapai maka tahap 
dalam penyelesaian masalah dapat kembali ke tahap yang diperkirakan terjadi kesalahan.

Indikator kemampuan pemecahan masalah berdasarkan tahapan pemecahan masalah IDEAL seperti pada tabel 1.

Tabel 2.1. Indikator pemecahan masalah IDEAL Tahap

Pemecahan

Masalah

Indikator

IDEAL

\begin{tabular}{|c|c|}
\hline $\begin{array}{l}\text { dentifika } \\
\text { lah }\end{array}$ & $\begin{array}{l}\text { Menyebutkan apa ya } \\
\text { diketahui dari soal }\end{array}$ \\
\hline $\begin{array}{l}\text { Menentukan } \\
\text { tujuan }\end{array}$ & $\begin{array}{l}\text { Menentukan apa yang } \\
\text { ditanyakan dari soal }\end{array}$ \\
\hline $\begin{array}{l}\text { Mencari } \\
\text { strategi yang } \\
\text { mungkin }\end{array}$ & $\begin{array}{ll}\text { a. } & \text { Mencari alternatif } \\
& \text { pemecahan masalah } \\
& \text { yang sesuai } \\
\text { b. } & \text { Menyatakan kembali } \\
\text { permasalahan } \\
\text { dengan } \\
\text { menggunakan } \\
\text { penalaran, variabel } \\
\text { dan persamaan } \\
\text { c. Menyusun model } \\
\text { d. } \\
\text { Menggunakan rumus }\end{array}$ \\
\hline $\begin{array}{l}\text { Melaksanakan } \\
\text { strategi }\end{array}$ & $\begin{array}{l}\text { Menerapkan perencanaan } \\
\text { pemecahan masalah untuk } \\
\text { memperoleh penyelesaian } \\
\text { dari masalah yang } \\
\text { diberikan dengan benar }\end{array}$ \\
\hline Mengkaji & Melihat/mengecek \\
\hline $\begin{array}{l}\text { kembali dan } \\
\text { mengevalusi } \\
\text { pengaruhnya }\end{array}$ & $\begin{array}{l}\text { kembali cara-cara } \\
\text { pemecahan masalah yang } \\
\text { telah dilakukan } \\
\text { Melihat/mengkaji } \\
\text { pengaruh strategi yang } \\
\text { digunakan dalam } \\
\text { pemecahan masalah }\end{array}$ \\
\hline
\end{tabular}

Pemecahan masalah IDEAL memiliki langkah-langkah yang sistematis namun setiap peserta didik memiliki kemampuan pemecahan masalah yang berbeda. Dalam penelitian ini proses pemecahan masalah geometri dianalisis berdasarkan teori Van Hiele.

\subsection{Tingkat Berpikir Geometri Berdasarkan Teori Van Hiele}

Teori Van Hiele dikembangkan pada tahun 1959 oleh dua pendidik matematika Belanda yaitu Pierre Van Hiele dan istrinya Dina
Van Hiele-Geldof. Teori Van Hiele mengusulkan lima tingkat perkembangan berpikir geometri seperti berikut: 1) tingkat visualisasi; 2) tingkat analisi; 3) tingkat deduksi informal; 4) tingkat deduksi informal; 5) tingkat rigor seperti berikut: 1) tingkat visualisasi; 2) tingkat analisi; 3) tingkat deduksi informal; 4) tingkat deduksi informal; 5) tingkat rigor (Kutluca, 2013). Yang mana dalam penelitian ini peneliti hanya akan meneliti pada tingkat analisis.

1. Tingkat analisis

Peserta didik dapat mengidentifikasi sifat bentuk bangun geometri tertentu (Patsiomitou, 2010; Pinar, 2014; Abu \& Abidin, 2010). Misalnya peserta didik dapat mengenali bahwa persegi panjang memiliki empat sisi dan empat sudut siku-siku serta sisi yang berlawanan sama panjang (Pinar, 2014).

Kriteria penskoran berdasarkan tes Geometri Van Hiele (VHG) dikembangkan oleh Usiskin (1982) menyatakan bahwa:

Pada tes VHG, setiap tingkat mempunyai lima pertanyaan. Jika peserta didik menjawab tiga, empat atau lima pada tingkat pertama dengan benar, dia mencapai tingkat pertama. Jika peserta didik (a) menjawab tiga pertanyaan atau lebih dari tingkat kedua; (b) memenuhi kriteria tingkat pertama; dan (c) tidak menjawab dengan benar tiga atau lebih pertanyaan dari tingkat 3,4 , dan 5 , peserta didik tergolong pada tingkat kedua.

Kriteria penskoran tersebut juga berlaku untuk tingkat 3, 4, dan 5. Jika peserta didik menjawab tiga atau lebih pertanyaan dengan benar pada tingkat 1,2 , dan 3 serta tidak menjawab dengan benar tiga atau lebih pertanyaan pada tingkat 4 dan 5 maka peserta didik tergolong tingkat 3 . Jika peserta didik menjawab tiga atau lebih pertanyaan dengan benar pada tingkat $1,2,3$, dan 4 serta tidak menjawab dengan benar tiga atau lebih pertanyaan pada tingkat 5 maka peserta didik 
tergolong tingkat 4. Jika peserta didik menjawab tiga atau lebih pertanyaan dengan benar pada tingkat $1,2,3,4$, dan 5 maka peserta didik tergolong tingkat 5 . Apabila peserta didik belum mencapai tingkat 1 atau visualisasi maka peserta didik dikategorikan pada tingkat previsualisasi. Pada tingkat previsualisasi peserta didik masih belum mengenal bentuk geometris secara global.

Penelitian yang relevan mengenai tingkat berpikir Van Hiele diantaranya yaitu Muhassanah, dkk (2014) menyatakan bahwa keterampilan geometri yang dimiliki peserta didik berdasarkan teori Van Hiele berbeda-beda dan berurutan sesuai dengan tingkat teori Van Hiele. Khoiri (2014) menyatakan bahwa pemahaman peserta didik pada konsep segiempat masih rendah namun pembelajaran berdasarkan teori Van Hiele mampu membangun pemahaman peserta didik pada konsep segiempat. Khoiriyah, dkk (2014) menyatakan bahwa tingkat berpikir peserta didik SMA paling tinggi mencapai analisis. Alex \& Mammen (2012) menyatakan bahwa mayoritas peserta didik kelas $\mathrm{X}$ berada pada tingkat previsualisasi. Pinar (2014) menyatakan bahwa tingkat berpikir geometri berdasarkan teori Van Hiele peserta didik SD rendah, ada hubungan sikap terhadap geometri dan prestasi matematika, namun tidak ada pengaruh terhadap gender.

Penelitian sebelumnya menggunakan tes geometri Van Hiele untuk mengetahui tingkat geometri peserta didik berdasarkan teori Van Hiele dengan membedakan perbedaan gender dan keterampilan geometri. Sedangkan penelitian ini menganalisis proses pemecahan masalah geometri subjek penelitian berdasarkan tingkat Van Hiele.

\subsection{Proses Pemecahan Masalah Geometri berdasarkan Teori Van Hiele}

Setiap peserta didik memiliki kemampuan yang berbeda dalam menyelesaikan masalah matematika. Begitu pula dalam proses pemecahan masalah geometri. Perbedaan antar peserta didik dalam menyusun dan mengolah informasi pada materi geometri bisa dikarenakan perbedaan tingkat berpikir geometri Van Hiele. Perbedaan tingkat berpikir geometri peserta didik mempengaruhi tiap peserta didik memahami materi dan permasalahan geometri karena peserta didik memiliki cara yang khas dalam menyusun dan mengolah informasi selama mempelajari materi geometri tersebut. Tabel 2.2 indikator proses pemecahan masalah IDEAL berdasarkan teori Van Hiele

\begin{tabular}{|c|c|c|}
\hline $\begin{array}{c}\text { Tingkat } \\
\text { berpikir } \\
\text { Van } \\
\text { Hiele }\end{array}$ & $\begin{array}{c}\text { Karakteristi } \\
\text { k }\end{array}$ & $\begin{array}{c}\text { Indikator Tingkat } \\
\text { Berpikir }\end{array}$ \\
\hline $\begin{array}{l}\text { Tingkat } 2 \\
\text { (analisis) }\end{array}$ & $\begin{array}{l}\text { Siswa mulai } \\
\text { mengenali } \\
\text { dan } \\
\text { mengaplikas } \\
\text { ikan suatu } \\
\text { ide } \\
\text { geometri, } \\
\text { mendeskrips } \\
\text { ikan dengan } \\
\text { benar } \\
\text { berbagai } \\
\text { sifat serta } \\
\text { dapat } \\
\text { mengidentifi } \\
\text { kasi Gambar } \\
\text { sebagai } \\
\text { bagian dari } \\
\text { Gambar } \\
\text { yang lebih } \\
\text { besar. }\end{array}$ & 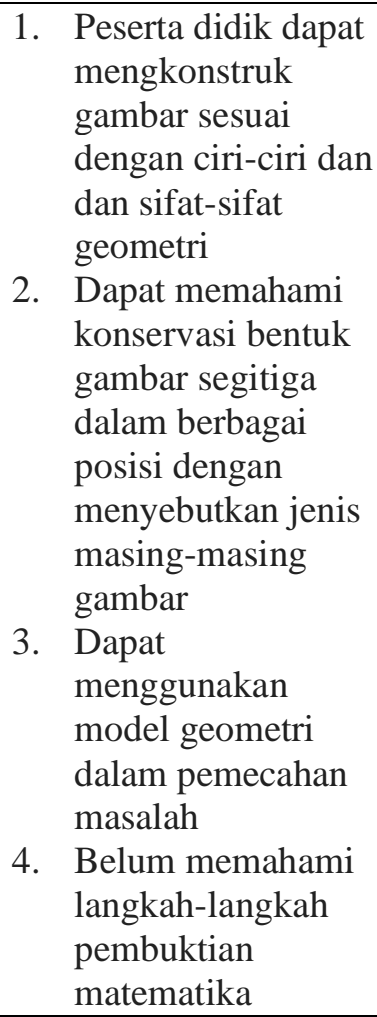 \\
\hline
\end{tabular}

\section{METODE PENELITIAN}

Penelitian ini dirancang untuk mengeksplorasi dan mendeskripsikan proses pemecahan masalah geometri berdasarkan teori Van Hiele. Oleh karena itu jenis penelitian yang digunakan dalam penelitian ini adalah deskriptif eksploratif. Pendekatan yang digunakan dalam penelitian ini adalah pendekatan kualitatif.

Subjek penelitian ini dibatasi pada peserta didik SMAN 2 Lumajang yang mencapai tingkat analisis. Subjek tingkat deduksi formal dan rigor tidak bisa diungkap dikarenakan subjek tidak ada yang mencapai tingkat tersebut. 


\section{Jurnal Noken 2(1) 28-39|2016} berupa:

Data yang diperoleh dalam penelitian ini

1. Data hasil tes geometri Van Hiele diperoleh dari tes geometri Van Hiele yang berupa pilihan ganda yang diberikan kepada peserta didik SMA. Data ini digunakan untuk mendapatkan subjek penelitian.

2. Data proses pemecahan masalah subjek penelitian diperoleh dari tes tertulis dan wawancara setelah subjek menyelesaikan masalah geometri. Data ini digunakan untuk menjawab masalah penelitian.

Peneliti pada penelitian kualitatif merupakan utama penelitian, dimana peneliti sekaligus sebagai perencana yang menetapkan fokus, memilih subjek, sebagai pelaksana pengumpulan data, menganalisis data serta menarik kesimpulan. Dalam teknik pengumpulan data, instrumen pendukung yang digunakan dalam penelitian ini di antaranya yaitu: 1) soal tes geometri Van Hiele; 2) soal tes pemecahan masalah; 3) pedoman wawancara; 4) alat perekam

\section{HASIL PENELITIAN}

Pada bab ini akan dipaparkan dan dianalisis data penelitian dari subjek yang terpilih. Subjek yang terpilih diantaranya yaitu AA dan DR yag mencapai tingkat visualisasi, RF dan GL yang mencapai tingkat analisis, serta FW dan AS yang mencpaai tingkat deduksi informal. Pemaparan hasil penelitian dilakukan secara terurut terhadap subjek dengan kategori tingkat 1 (visualisasi), dilanjutkan dengan subjek dengan kategori tingkat 2 (analisis) dan dilanjutkan dengan subjek dengan kategori tingkat 3 (deduksi informal).

\subsection{Proses Pemecahan Masalah Geometri berdasarkan Teori Van Hiele}

Setelah terpilih 6 subjek penelitian, selanjutnya masing-masing subjek diminta untuk mengerjakan soal pemecahan geometri yang diadopsi dari soal olimpiade nasional. Pengumpulan data dilakukan dengan hasil pekerjaaan subjek dan hasil wawancara. Data diperoleh dengan merekam proses penyelesaian subjek, pengambilan data wawancara dengan menggunakan handphone.

\subsubsection{Analisis proses pemecahan masalah} subjek yang mencapai tingkat analisis

1. Mengidentifikasi masalah

Hasil pemecahan masalah subjek RF pada tahap mengidentifikasi masalah seperti pada Gambar 8, sedangkan subjek GL seperti Gambar 9 berikut.

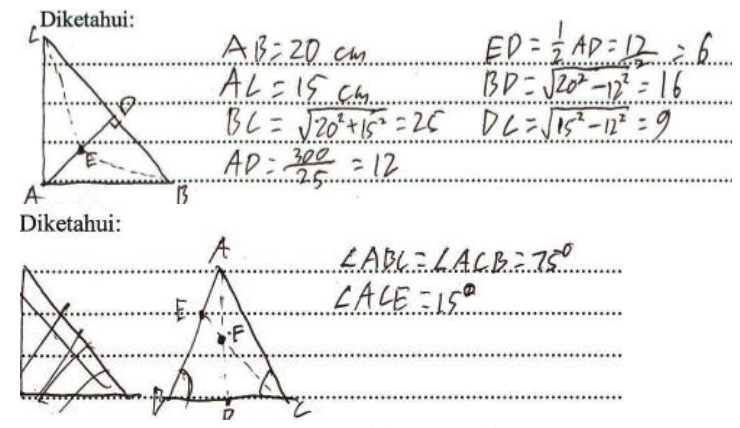

Gambar 8. Hasil tes tulis

mengidentifikasi masalah subjek RF

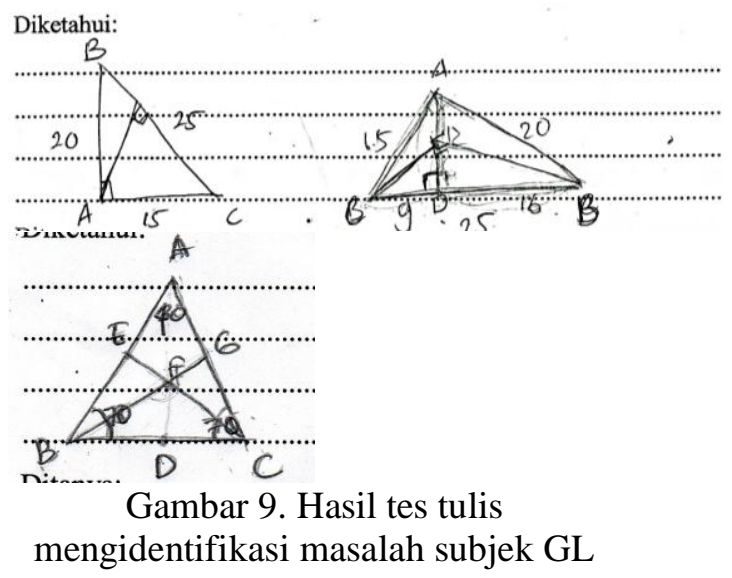

Berdasarkan hasil tes tulis pada tahap mengidentifikasi masalah, subjek RF mengidentifikasi masalah dengan menyebutkan yang diketahui dari permasalahan serta mencari panjang garis yang belum diketahui. Sedangkan subjek GL mengidentifikasi masalah dengan membuat bentuk geometrinya dengan ukuran garis yang sesuai dengan permasalahan. Namun kedua subjek masih ada kesalahan dalam penulisan ukuran sudut. Kedua subjek menuliskan $\angle A B C=\angle A C B=75^{\circ} \quad$ sedangkan 
penulisan yang benar yaitu $u \angle A B C=$ $u \angle A C B=75^{\circ}$. Hal ini menunjukkan bahwa subjek RF maupun subjek GL dapat mengidentifikasi masalah dengan menyebutkan yang diketahui dari permasalahannamun kurang sistematis serta ada kesalahan dalam penulisan besar sudut.

Berdasarkan hasil wawancara dengan kedua subjek, kedua subjek mengidentifikasi menggunakan bahasanya sendiri. Hal ini sesuai dengan hasil wawancara kedua subjek mengenai mengidentifikasi masalah yaitu

Peneliti : "yang dimaksud dari soal ini bagaimana?"

Subjek : "jadi diberitahukan ada sebuah segitiga siku-siku di $A$. dimana panjang sisi $A B=20 \mathrm{~cm}$ dan sisi $A C=15$. Yang ditanya $B E$ eh lalu dikasi garis tinggi yang tegak lurus dengan sisi BC. Ditengah-tengah $A D$ ada titik E. Yang ditanya nilai $B E+C E$ "

Peneliti : "ada kendala gak?"

Subjek : "tidak ada bu"

Sedangkan hasil wawancara dengan subjek GL yaitu

Peneliti : "yang diketahui dari soal ini apa?"

Subjek GL : "kan ada segitiga siku-siku di $A . A B=20 \mathrm{~cm}, A C=15 . A D$ garis tinggi dari segitiga. $E$ titik tengan AD. Tapi langsung saya gambar gini bu" a

Berdasarkan hasil tes tulis dan hasil wawancara dengan subjek RF dan subjek GL maka dapat disimpulkan bahwa subjek yang mencapai tingkat analisis mampu mengidentifikasi masalah geometri dengan menyebutkan yang diketahui dari permasalahan dengan bahasanya sendiri namun kurang sistematis.

2. Menentukan tujuan

Hasil pemecahan masalah subjek RF pada tahap menentukan tujuan seperti pada Gambar 10, sedangkan subjek GL seperti Gambar 11

berikut.

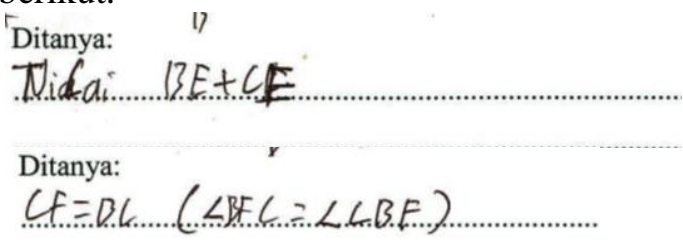

Gambar 10. Hasil tes tulis menentukan tujuan oleh subjek RF

Ditanya: $\quad-$

\section{Ditanya:}

$C F=B C$

Gambar 11. Hasil tes tulis menentukan tujuan oleh subjek GL

Subjek RF maupun subjek GL menentukan tujuan dalam permasalahan sesuai dengan yang ditanyakan pada permasalahan. Kedua subjek menentukan tujuan dalam permasalahan geometri menggunakan bahasanya sendiri. Hasil wawancara dengan subjek yang mencapai tingkat analisis mengenai menentukan tujuan dalam permasalahan pertama yaitu

$$
\text { Subjek : "yang dicari }
$$
nilai panjang $B E+C E$ “

Sedangkan hasil wawancara mengenai menentukan tujuan pada permasalahan kedua yaitu

$$
\text { Subjek : "ditanya }
$$

disuruh buktikan $C F=B C$,

Berdasarkan hasil tes tulis dan hasil wawancara dengan subjek RF maupun subjek GL dapat dikatakan bahwa subjek yang mencapai tingkat analisis menentukan tujuan dengan menyebutkan yang ditanyakan dalam permasalahan geometri tersebut dengan menggunakan bahasanya sendiri.

3. Mencari strategi yang mungkin

Hasil pemecahan masalah subjek RF pada tahap mengidentifikasi masalah seperti pada Gambar 12, sedangkan subjek GL seperti Gambar 13 berikut. 
Mencari strategi yang mungkin (menyusun model/rumus)

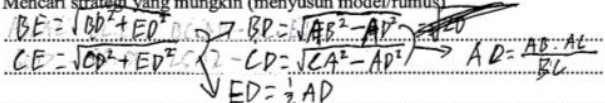

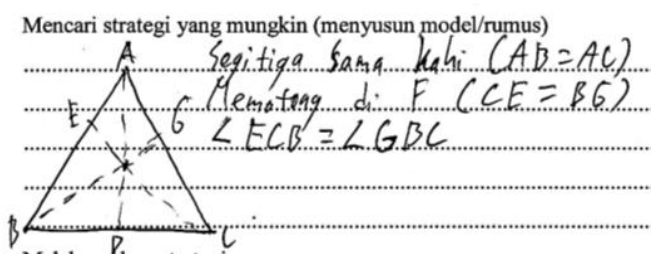

Gambar 12. Hasil tes tulis mencari strategi yang mungkin dalam memecahkan masalah oleh subjek RF

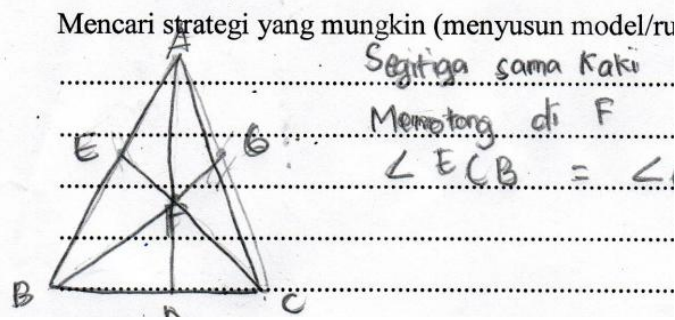

Gambar 13. Hasil tes tulis mencari strategi yang mungkin dalam memecahkan masalah oleh subjek

GL

Subjek RF memecahkan masalah geometri dengan menyusun langkah-langkah atau mencari strategi yang mungkin untuk digunakan dalam memecahkan masalah geometri. Sedangkan untuk subjek GL tidak menuliskan langkah-langkah yang akan digunakan dalam memecahkan masalah pertama, namun dari hasil wawancara subjek GL dapat menjelaskan strategi yang akan digunakan dalam memecahkan masalah.

Hasil wawancara dalam memecahkan masalah mengenai mencari strategi yang mungkin digunakan untuk memecahkan masalah yaitu

Peneliti

$$
\begin{aligned}
& \text { : "strategi untuk } \\
& \text { menyelesaikan } \\
& \text { ini } \\
& \text { bagaimana?" } \\
& : \text { "saya cuma } \\
& \text { pake sudut- }
\end{aligned}
$$

Subjek sudut dalam

segitiga bu"

Berdasarkan hasil tes tulis dan hasil wawancara, subjek yang mencapai tingkat analisis mencari strategi dengan cara menuliskan cara atau rumus yang akan digunakan untuk memecahkan masalah namun kurang sistematis.

4. Melaksanakan strategi

Hasil pemecahan masalah subjek RF pada tahap melaksanakan strategi seperti pada Gambar 14, sedangkan subjek GL seperti Gambar 15 berikut.

$$
\begin{aligned}
& \text { Melaksanakan strategi } \\
& A D=\frac{20 \cdot 15}{35}=12, E D=\frac{1}{2} \cdot 12=6 \\
& B D=\sqrt{\left.20^{2}-1\right)^{2}}=16 \Rightarrow B E=\sqrt{16^{2}+6^{2}}=\sqrt{256+36}=\sqrt{292}: 2 \sqrt{73} \\
& C D=\sqrt{15^{2}-12^{2}}=9 \Rightarrow C E=\sqrt{9^{2}+6^{2}}=\sqrt{81+36}=\sqrt{117}=3 \sqrt{13}
\end{aligned}
$$
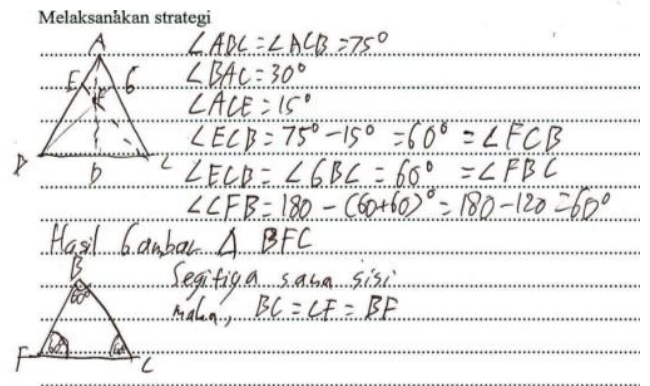

Gambar 14. Hasil tes tulis mencari melaksanakan dalam memecahkan masalah oleh subjek RF 


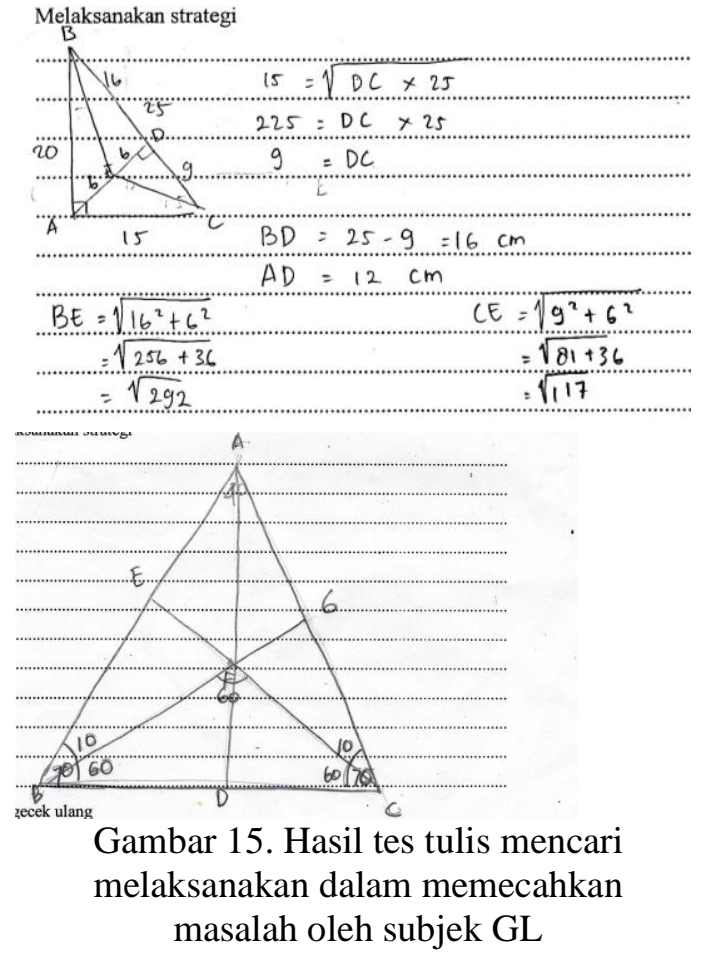

Berdasarkan hasil pemecahan masalah geometri, subjek RF maupun subjek GL melaksanakan strategi dari strategi yang telah disusun namun kurang sistematis. Kedua subjek melaksanakan strategi pada permasalahan kedua dengan bantuan bangun geometri. Selain itu, kedua subjek melakukan perhitungan tanpa menuliskan rumusnya, misalnya subjek GL dan subjek RF yang menuliskan $B E=\sqrt{16^{2}+6^{2}}$ tanpa menuliskan 16 dan 6 merupakan panjang sisi apa. Kedua subjek setelah melakukan perhitungan tersebut tidak menuliskan jawaban dari apa yang ditanyakan dalam permasalahan tersebut.

Berdasarkan hasil wawancara, subjek RF maupun subjek GL melaksanakan strategi sesuai dengan strategi yang telah disusun sebelumnya untuk memecahkan masalah geometri tersebut. Hal ini terlihat dari kemampuan kedua subjek dalam menjelaskan langkah demi langkah apa saja yang harus dikerjakan dalam memecahkan masalah tersebut meskipun langkah-langkahnya kurang sistematis serta kurang tepatnya penulisan ukuran sudut. Berikut hasil wawancara dengan subjek RF terkait dengan permasalahan geometri tersebut

$\begin{array}{cl}\text { Peneliti } & \text { : "melaksanakan strategi } \\ & \text { yang sudah dibuat ini ada } \\ \text { kendala tidak?" } & \\ \text { Subjek } & \text { awalnya saya menggunakan } \\ & \text { sinus cosinus tapi karena } \\ & \text { saya tidak terlalu suka sama } \\ & \text { itu jadi saya kembali lagi } \\ & \text { pake sudut ini" }\end{array}$

Sedangkan hasil wawancara dengan subjek GL yaitu

Peneliti

$$
\text { : "gimana cara }
$$

Subjek GL : "ini saya langsung gambar bu... ini kan gini ya bu,, sudut ECB itu kan didapat $60^{\circ}$. Terus GBC itu juga sama bu $60^{\circ}$. Jadi segitiga ini (segitiga BCF) itu sudutnya $60^{\circ}$ semua. $Y a$ udah bu berarti segitiga sama sisi. Bener gak bu?"

Berdasarkan hasil tes tulis dan wawancara dengan subjek RF dan subjek GL maka subjek yang mencapai tingkat analisis melaksanakan strategi pemecahan masalah geometri sesuai dengan strategi yang telah dibuatnya meskipun kurang sistematis.

5. Mengkaji kembali dan mengevaluasi pengaruhnya

Hasil pemecahan masalah subjek RF pada tahap mengkaji kembali dan mengevaluasi pengaruhnya seperti pada Gambar 16, sedangkan subjek GL seperti Gambar 17 berikut.

Mengecek ulang

Gambar 16. Hasil tes tulis mengkaji kembali dan mengevaluasi pengaruhnya dalam memecahkan masalah oleh subjek RF 


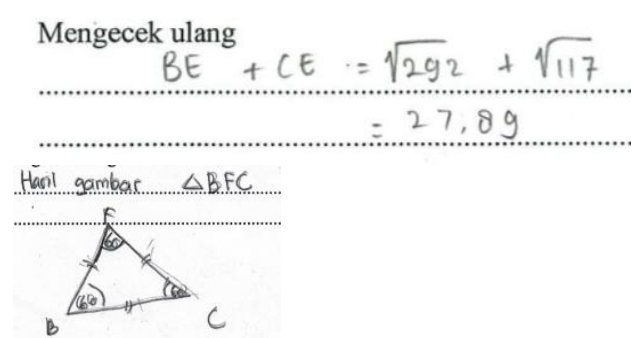

Gambar 17. Hasil tes tulis mengkaji kembali dan mengevaluasi pengaruhnya dalam memecahkan masalah oleh subjek RF

Subjek RF maupun subjek GL melaksanakan langkah mengkaji kembali atau mengecek ulang tidak menuliskan cara pengecekan ulangnya. Kedua subjek melakukan pengecekan pada setiap proses pemecahan masalah. Hal ini sesuai dengan hasil wawancara dengan subjek RF sebagai berikut

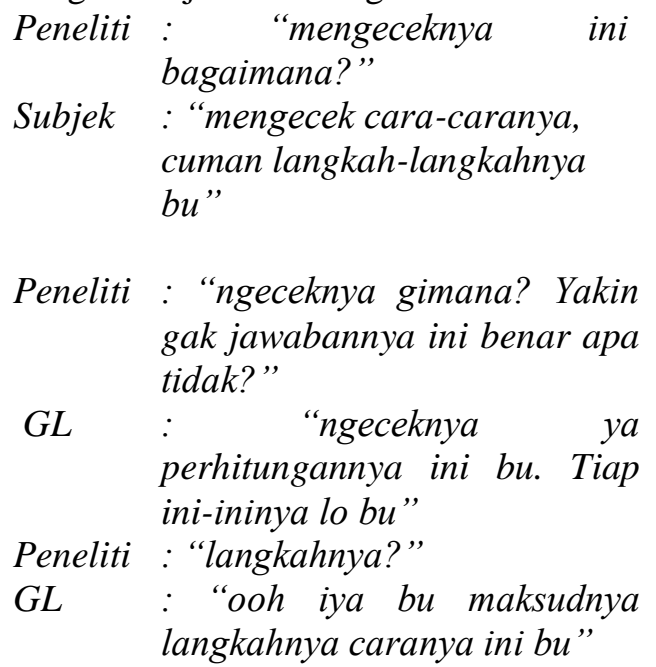

Berdasarkan hasil tes tulis
pemecahan masalah dan hasil wawancara, subjek yang mencapai tingkat analisis melaksanakan setiap langkah pemecahan masalah IDEAL. Subjek mengidentifikasi masalah dengan menyebutkan yang diketahui dari permasalahan dengan kurang sistematis. Kemudian subjek menentukan tujuan pada permasalahan dengan menyebutkan yang ditanyakan pada permasalahan. Kemudian pada tahap mencari strategi yang mungkin subjek menuliskan cara atau rumus yang akan digunakan untuk memecahkan masalah tersebut. Subjek tidak menuliskan strategi secara runtut sesuai dengan langkah-langkah untuk memecahkan masalah tersebut. Kemudian dilanjutkan melaksanakan strategi sesuai dengan strategi yang telah dibuatnya. Karena subjek tidak menuliskan strategi secara runtut maka dalam melaksanakan strategi subjek juga tidak menuliskan secara runtut, bahkan subjek tidak menuliskan rumus yang digunakan. Setelah menyelesaikan subjek mengkaji kembali dengan cara mengecek setiap langkah yang telah dikerjakan. Subjek yang mencapai tingkat analisis memecahkan masalah menggunakan sifat-sifat bangun yang sudah diketahui namun tidak memformulasikan secara formal.

Berdasarkan pemaparan tersebut maka proses pemecahan masalah IDEAL oleh subjek Van Hiele yang mencapai tingkat analisis seperti pada Gambar 18.

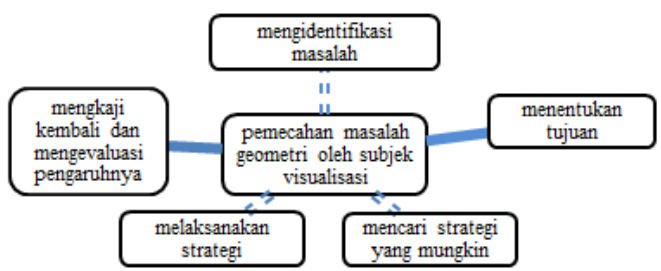

Gambar 18. Proses pemecahan masalah

IDEAL oleh subjek Van Hiele yang mencapai tingkat analisis

Keterangan:

$$
\begin{array}{r}
\text { E E }=\quad \text { dikerjakan dengan kurang } \\
\text { sistematis serta salah penulisan } \\
: \text { dikerjakan dengan sistematis }
\end{array}
$$

\subsection{Pembahasan}

Hasil penelitian yang telah diuraikan di atas menunjukkan bahwa proses pemecahan masalah geometri yang dimiliki subjek berdasarkan tingkat berpikir Van Hiele. Subjek yang mencapai tingkat analisis memecahkan masalah dengan mengidentifikasi masalah, menentukan tujuan, mencari strategi yang mungkin, melaksanakan strategi serta mengkaji 
kembali dan mengevaluasi pengaruhnya dengan kurang sistematis. Subjek yang mencapai tingkat analisis memecahkan masalah dengan menggunakan bahasanya sendiri namun salah dalam penulisan ukuran sudut. Hal ini sesuai dengan hasil penelitian Noriza, dkk (2015) bahwa peserta didik tingkat analisis dapat mengidentifikasi unsur-unsur yang diketahui dan ditanya. Peserta didik dapat mengembangkan model matematika meskipun belum lengkap. Muhassanah, dkk (2014) menyatakan bahwa tingkat analisis tidak dapat menyebutkan rumus yang digunakan.

Berdasarkan hasil pemaparan proses pemecahan masalah berdasarkan tingkat Van Hiele menunjukkan bahwa proses pemecahan masalah subjek berbeda-beda. Hal ini sesuai dengan Muhassanah, dkk (2014) yang menunjukkan keterampilan geometri yang dimiliki peserta didik berdasarkan tingkat berpikir Van Hiele berbeda-beda dan berurutan sesuai dengan tingkat berpikir Van Hiele. Abdussakir (2010) menyatakan bahwa salah satu tujuan pembelajaran geometri adalah agar peserta didik dapat menjadi pemecah masalah yang baik. Meskipun demikian, yang terjadi selama ini adalah geometri merupakan materi yang sulit dipahami dan cenderung dibenci oleh kebanyakan peserta didik. Seperti yang diutarakan oleh Adolphus (2011) bahwa materi matematika yang dianggap sulit dan ditakuti siswa dalam pelajaran matematika adalah materi geometri. Hal ini mengakibatkan siswa enggan belajar geometri dan pada akhirnya tujuan pembelajaran geometri untuk mengembangkan kemampuan pemecahan masalah tidak dapat dicapai.

Berdasarkan pemaparan tersebut maka untuk memperbaiki kualitas pembelajaran geometri melalui pembelajaran berdasarkan teori Van Hiele yang melalui lima tahap pembelajaran. Tahap pembelajaran geometri Van Hiele meliputi tahap 1 informasi, guru dan peserta didik menggunakan tanya jawab dan kegiatan tentang objek-objek yang dipelajari pada tahap berpikir yang bersangkutan. Guru mengajukan pertanyaan kepada peserta didik sambil melakukan observasi. Tahap 2 orientasi langsung, peserta didik menggali topik yang dipelajari melalui alat-alat yang cermat disiapkan guru. Tahap 3 penjelasan, peserta didik menyatakan pandangan yang muncul mengenai struktur yang diobservasi. Tahap 4 orientasi bebas, peserta didik menghadapi tugastugas yang lebih komplek berupa tugas yang memerlukan banyak langkah, tugas yang dilengkapi dengan banyak cara dan tugas-tugas open ended. Selanjutnya tahap 5 integrasi, peserta didik meninjau kembali dan meringkas apa yang telah diketahui. Guru dapat membantu dalam membuat sintesis ini dengan melengkapi survey secara global tentang apa yang telah dipelajari peserta didik.

Kualitas pengetahuan peserta didik tidak ditentukan dari akumulasi pengetahuan peserta didik atau seberapa banyak pengetahuan yang dimilikinya, tetapi lebih ditentukan oleh proses berpikir yang digunakan. Hal ini sesuai dengan Azimi dan Irawan (2012) bahwa penerapan pembelajaran geometri Van Hiele dapat meningkatkan tahap berpikir siswa dari tahap visualisasi ke tahap analisis. Sehingga melalui pembelajaran yang sesuai dengan tingkat berpikir peserta didik maka peserta didik dapat memecahkan masalah dengan baik.

\section{PENUTUP}

\subsection{Kesimpulan}

Berdasarkan analisis dan pembahasan yang telah diuraikan pada Bab IV diperoleh kesimpulan sebagai berikut

1. Pemecahan masalah pada geometri peserta didik yang mencapai tingkat berpikir visualisasi adalah dengan mengidentifikasi masalah dan menentukan tujuan dengan menggunakan bahasa soal. Peserta didik tidak mencari strategi yang mungkin, melaksanakan strategi maupun mengkaji kembali dan mengevaluasi pengaruhnya.

2. Pemecahan masalah pada geometri peserta didik yang mencapai tingkat berpikir analisis adalah melalui kelima langkah pemecahan masalah IDEAL dengan menggunakan bahasanya sendiri namun kurang sistematis. Subjek yang mencapai tingkat analisis memecahkan masalah menggunakan sifat-sifat bangun yang sudah 
diketahui namun tidak memformulasikan secara formal.

3. Pemecahan masalah pada geometri peserta didik yang mencapai tingkat berfikir deduksi informal adalah melalui kelima langkah pemecahan masalah IDEAL dengan sistematis dan menggunakan bahasanya sendiri. Peserta didik memecahkan masalah secara runtut dan sistematis pada setiap cara atau langkah yang digunakan.

\subsection{Saran}

Hasil penelitian ini diharapkan dapat memberikan sumbangan pemikiran sebagai usaha meningkatkan kemampuan dalam bidang pendidikan, khususnya bidang matematika. Saran yang dapat disampaikan penulis sehubungan dengan hasil penelitian ini adalah sebagai berikut.

1. Berdasarkan hasil proses pemecahan masalah geometri yang rendah maka guru perlu menerapkan pembelajaran geometri berdasarkan Van Hiele sehingga dengan konsep geometri yang matang diharapkan peserta didik dapat meningkatkan kemampuan dalam memecahkan masalah geometri.

2. Berdasarkan keterbatasan dari penelitian ini yang hanya menganalisis proses pemecahan masalah geometri pada tingkat visualisasi, analisis, dan deduksi informal maka diharapkan penelitian selanjutnya dilanjutkan untuk menganalisis proses pemecahan masalah geometri pada tingkat visualisasi, analisis, deduksi informal, deduksi formal dan rigor.

\section{Daftar pustaka}

Abdullah, A. H \& Zakaria, E. (2013). Enhancing Students' Level of Geometric Thinking Through Van Hiele's Phase-based Learning. Indian Journal of Science and Technology. Vol. 6, No. 5

Abu, M. S. \& Abidin, Z. Z. (2013). Improving the Levels of Geometric Thinking of Secondary School Students Using Geometry Learning Video based on Van Hiele Theory. International Journal of
Evaluation and Research in Education (IJERE). Vol. 2, No. 1

Alex, J. K. \& Mammen, J. (2012). A Survey of South African Grade 10 Learners' Geometric Thinking Levels in Terms of the Van Hiele Theory. Anthropologist. Vol. 14. No. 2

Al-Migdady, A. M. (2014). Skilled-Unskilled mathematical Problem Solvers: Jordanian-Students' Differences in Solving Geometrical Problems. European Scientific Journal. Vol. 10, No. 25

Aydoğdu, M. Z \& Keşan, C. (2014). A Research On Geometry Problem Solving Strategies Used By Elementary Mathematics Teacher Candidates. Journal of Educational and Instructional Studies. Vol. 4, No. 1

Bahmaei, F. (2011). Mathematical modelling in primary school, advantages and challenges. Journal of Mathematical Modelling and Application. Vol.1, No. 9

Balitbang. (2012). Daya Serap Ujian Nasional Tahun 2012

Breyfogle, M. L. \& Lynch, C. M. (2010). To Analyze Students Geometric Thinking,Use Both Formative and Summative Assessments and Move Students along the Van Hiele Model of Thought. Mathematicas Teaching in the Middle School. Vol. 16. No. 4

Kartono. (2013). Disain Asesmen Kemampuan Pemecahan Masalah Matematika Berorientasi pada PISA dengan Strategi Ideal Problem Solver. Prosiding Seminar Nasional Evaluasi Pendidikan Tahun 2013

Khoiriyah, N, et al. (2013). Analisis Tingkat Berpikir Siswa Berdasarkan Teori Van Hiele Pada Materi Dimensi Tiga Ditinjau Dari Gaya Kognitif Field Dependent dan Field Independent. Jurnal Pendidikan Matematika Solusi. Vol. 1, No. 1

Kutluca, T. (2013). The Effect Of Geometry Instruction with Dynamic Geometry Software; Geogebra on Van Hiele Geometry Understanding Levels of 
Students. Academic Journals. Vol. 8. No. 17

Mohamed, L \& Waheed, H. (2011). Secondary Students' Attitude towards Mathematics in a Selected School of Maldives. International Journal of Humanities and Social Science. Vol. 1, No. 15

Muhassanah, N, et al. (2014). Analisis Keterampilan Geometri Siswa dalam Memecahkan Masalah Geometri Berdasarkan Tingkat Berpikir Van Hiele. Journal Elektronik Pembelajaran Matematika. Vol. 2, No. 1

NCTM. (2010). A Research on Geometry Problem Solving Strategies Used by Elementary Mathematics Teacher Candidates

Özerem, A. (2012). Misconceptions In Geometry And Suggested Solutions For Seventh Grade Students. International Journal of New Trends in Arts, Sport \& Science Education. Vol. 1, No. 4

Patsiomitou, S. \& Emvalotis, A. (2010). Students Movement Through Van Hiele Levels in a Dynamic Geometry Guided Reinvention Process. Journal of Mathematics and Technology.

Pinar, A. (2014). Predictor Variables For Primary School Students Related To Van Hiele Geometric Thinking. Journal of Theory and Practice in Education. Vol. 10, No.1

Prasetya, A. \& Widodo, K. (2012). Model Ideal Problem Solving untuk Pencapaian
Kemampuan Pemecahan Masalah di Kelas Olimpiade. Lembaran Ilmu Kependidikan. Vol. 41. No. 1

Purnomo, E. A. \& Mawarsari, V. D. (2014). Peningkatan Kemampuan Pemecahan Masalah Melalui Model Pembelajaran Ideal Problem Solving Berbasis Project Based Learning. JKPM. Vol. 1, No. 1

Rofiah, S, et al. (2013). Penyusunan Instrumen Tes Kemampuan Berpikir Tingkat Tinggi Fisika pada Siswa SMP. Jurnal Pendidikan Fisika. Vol. 13, NO. 2

Saragih, S \& Habeahan, W. L. (2014). The Improving of Problem Solving Ability and Students'Creativity Mathematical by Using Problem Based Learning in SMP Negeri 2 Siantar. Journal of Education and Practice. Vol. 5, No. 35

Sugiyanto \& Priyono. (2013). Pengaruh Metode Pembelajaran Pemecahan Masalah, Retensi Belajar, dan Motivasi Belajar terhadap Hasil Belajar Siswa SMK. Teknologi dan Kejuruan. Vol. 36, No. 1

Susiana, E. (2010). IDEAL Problem Solving dalam Pembelajaran Matematika. Jurnal Matematika Kreatif-Inovatif. Vol. 1, No. 2

Usiskin, Z. (1982). Van Hiele Levels and Achievement in Secondary School Geometry. Chicago: Kimbark Avenue

Vojkuvkova, I. (2012). The van Hiele Model of Geometric Thinking. WDS'12 Proceedings of Contributed Papers 